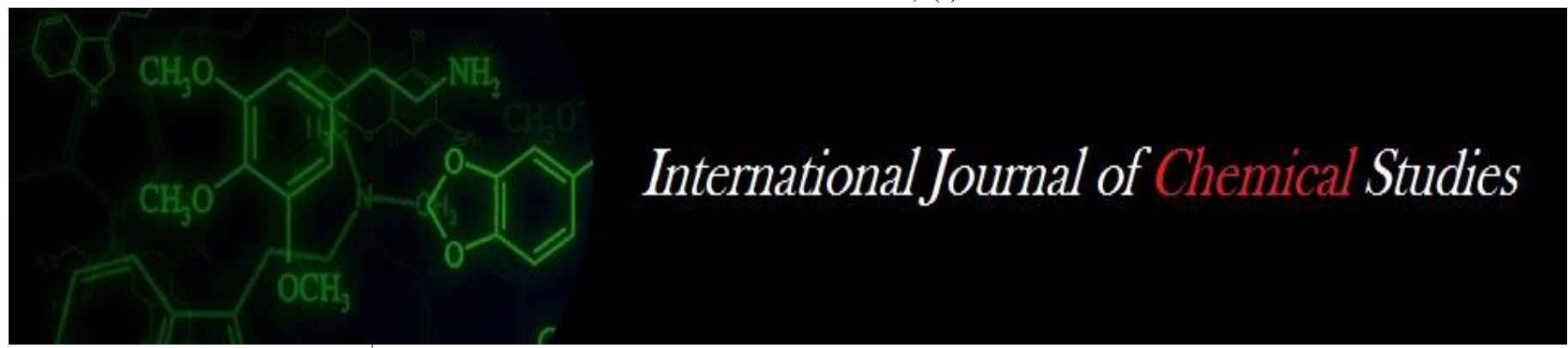

P-ISSN: 2349-8528

E-ISSN: 2321-4902

www.chemijournal.com

IJCS 2020; 8(1): 2736-2740

(C) 2020 IJCS

Received: 04-11-2019

Accepted: 06-12-2019

Chaudhari Bhoomiben Bharatbhai Amul Dairy, KDCMPU Ltd.

Anand, Gujarat, India

Patel Amitkumar Manojbhai

SMC College of Dairy Science,

AAU, Anand, Gujarat, India

Smitha Balakrishnan

SMC College of Dairy Science,

AAU, Anand, Gujarat, India

Corresponding Author:

Patel Amitkumar Manojbhai SMC College of Dairy Science, AAU, Anand, Gujarat, India

\section{Sensory, physico-chemical, microbial and textural changes in whey protein concentrate based extruded snack food during storage}

\author{
Chaudhari Bhoomiben Bharatbhai, Patel Amitkumar Manojbhai and \\ Smitha Balakrishnan
}

DOI: $\underline{\text { htps://doi.org/10.22271/chemi.2020.v8.i1ap.8684 }}$

\begin{abstract}
Extruded snacks are gaining recognition as well as appreciation these days due to their ready-to-eat nature, delicious taste and appealing look. Combination of lysine rich whey protein concentrate with lysine deficient cereal protein has synergistic effect that imparts a high nutritional value to the mixed protein in the product. The milk solids based extruded snack food and control sample were stored at room temperature $\left(37 \pm 2{ }^{\circ} \mathrm{C}\right)$ after packaging in MET PET material. The whey protein concentrate based extruded snack food samples and control sample were analyzed for changes in sensory characteristics, physico-chemical properties and textural properties as well as for microbiological quality at 15 days interval. Sensory scores, fracturability for experimental sample and control decreased while moisture, water activity and hardness increased during entire storage period. The Standard plate count decreased while coliform count and yeast and mold count were found absent till 180 days of storage.
\end{abstract}

Keywords: Whey protein concentrate, extruded snack food, extrusion cooking, twin screw extruder

\section{Introduction}

Snacks are a category of foods which are consumed during the meals to satiate the hunger. Snack foods are the first commercial extruded products and today, food manufacturers produce many foods and consumption of the extruded foods has been increasing. Owing to its convenience and low cost, snack foods consumption by all age groups, including adolescents and children has increased during the last twenty-five years (Sebastian et al., 2008) ${ }^{[15]}$. Snack food industry has been facing pressure from regulatory agencies to deliver healthier snack products. The snack market in India is quite large and diverse consisting of more than 1000 variants and about 300 types of savouries (Conti-Silva et al., 2012; Brennan et al., 2013) ${ }^{[8,3]}$.

Extrusion cooking is used for various food products such as snack food, baby food, breakfast cereals etc. (Huber, 2001) ${ }^{[9]}$. It is a low cost, energy efficient, versatile process which produces a high-quality product continuously without creating effluents. Whole grains, for instance corn and rice are often used to formulate healthy snack products using extrusion due to its relatively high starch content, bland taste and hypoallergenicity (Chaiyakul et al., 2009) [6]. Entire or partial incorporation of legume flour into ready-to-eat snack product have been proven to be desirable. However, several studies have indicated that partial substitution of cereal flour with high fibre and protein ingredients, for instance legume flour, can negatively affect the texture, expansion and overall acceptability of ready-to-eat snack products (Anton $e t$ al., 2009; Pastor-Cavada et al., 2011) ${ }^{[2,12]}$. Whey protein concentrate (WPC) represents a protein source with considerable potential for blending with varieties of food products to improve their nutritional value and functional properties.

Extrusion cooking is a modern high-temperature short-time (HTST) processing technology using high pressure, large shear forces and intensive mixing (Zheng \&Wang, 1994). Under these conditions, the raw materials are subject to protein denaturation, starch gluten formation and plasticization of the complete volume. The evolved plasticized volume expands through the die due to rapid fall in pressure, to form an extrudate with characteristic properties (Cai et al., 1995) ${ }^{[5]}$. In extrusion cooking, not only feed ingredients, but also extrusion parameters for instance feed moisture, screw speed, barrel temperature, and feed ratio are responsible for end 
product quality. The present study was conceptualized to access the Sensory, physico-chemical, microbial and textural changes in whey protein concentrate based extruded snack food during storage.

\section{Materials and Method \\ Raw Materials}

Good quality corn, rice and bengal gram flour was procured from local market of Anand. Whey protein concentrate (WPC) containing 70\% protein (WPC-70) was purchased from Arla Foods Pvt. Ltd. Commercially available good quality crystal iodised salt (TATA brand) was procured from local market and used in the study.

\section{Equipment / Instruments}

The equipment and instruments used in the present study are detailed below:

Equipment used in the present study included hot air oven (Model No. IK-III, IKON, India), analytical balance (Sartorius, England), vortex mixture (SAIF Surgical \& Scientific Equipment, Gujarat), Kjeldahl protein estimation unit (Model- KPS 006L, Kjel-Plus digestion and distillation units, M/s. Pelican Instruments, Chennai, India), muffle furnace (Model No. EIE-500 $(5 \mathrm{~kW})$, Erection \& Instrumentation Engineers, Ahmedabad, India), water activity meter (Hygrolab 3, Rotronic Measurement Solutions AG, Switzerland), texture analyser (Stable Micro Systems, UK), co-rotating twin screw extruder (BTPL lab model, Basic Technology Pvt. Ltd. Kolkata, India).

\section{Glasswares}

All glasswares used in the study were of standard quality supplied by authorized dealers. In case of specific experiments, the calibrated glasswares as specified by Bureau of Indian Standards (BIS, 1981) ${ }^{[4]}$ were used.

\section{Chemicals}

All the chemicals used in the preparation of different reagents were of analytical grade (AR) and were procured from standard companies. The reagents required for analysis were freshly prepared adopting standard procedures.

\section{Packaging Materials}

Extruded snack after drying was packed in metallized polyethylene terephthalate (MET PET) pouches of 12 microns thickness and the pouches were stored at $37 \pm 2{ }^{\circ} \mathrm{C}$.

\section{Manufacture of WPC based Extruded Snack Food}

Preliminary trails were carried out for selection of various ingredients like corn flour, rice flour, bengal gram flour and milk solids sources. Based on preliminary trials, total flour weight $(100 \mathrm{~g})$ consisted of rice flour, corn flour and bengal gram flour. Based on results from preliminary studies the proportion of Bengal gram flour was kept constant as 5 percent of total flour. Remaining 95 percent of flour weight was be made up of rice flour and corn flour (Rice: Corn flour ratio: 0.5). Water was added at the rate of 10 percent of total flour weight and its concentration was kept constant. WPC-70 was added at the rate of 10 percent of total flour weight. Salt at the level of 2 percent of the flour weight was incorporated in to the flour mixture. The composite flour mixture was sieved and then filled in low density polyethylene (LDPE) pouches and kept for preconditioning at room temperature for $2 \mathrm{~h}$. The extrusion cooking parameters were as follows barrel temperature: $110{ }^{\circ} \mathrm{C}$, extruder rpm: 330, feeder rpm: 15 , cutter rpm: 160 (based on preliminary trials).

\section{Results and Discussion}

The whey protein concentrate based extruded snack food T2 and control sample $\mathrm{T} 1$ were stored at room temperature $(37 \pm 2$ $\left.{ }^{\circ} \mathrm{C}\right)$ after packaging in MET PET material. The whey protein concentrate based extruded snack food samples were analyzed for changes in sensory characteristics, physico-chemical properties, textural characteristics as well as for microbiological quality at 15 days interval.

\section{Changes in the Sensory Characteristics of Whey Protein Concentrate Based Extruded Snack Food during Storage \\ The changes in sensory characteristics of samples T1 and T2 packed in MET PET and stored at room temperature $(37 \pm 2$ $\left.{ }^{\circ} \mathrm{C}\right)$ is shown in the Table 1 . The flavour, colour and appearance, texture, volume expansion and overall acceptability scores of $\mathrm{T} 1$ and $\mathrm{T} 2$ decreased at the end of 180 days of storage at room temperature $\left(37 \pm 2{ }^{\circ} \mathrm{C}\right)$.}

Table 1: Influence of storage period on sensory characteristics of extruded snack food

\begin{tabular}{|c|c|c|c|c|c|c|c|c|c|c|c|c|c|c|}
\hline \multirow{2}{*}{ Types of extruded food } & \multicolumn{13}{|c|}{ Storage period (days) } & \multirow{2}{*}{ Average (treatments) } \\
\hline & $\mathbf{0}$ & 15 & 30 & 45 & 60 & 75 & 90 & 105 & 120 & 135 & 150 & 165 & 180 & \\
\hline \multicolumn{15}{|c|}{ Flavour score } \\
\hline $\mathrm{T}_{1}$ & 7.90 & 7.74 & 7.53 & 7.33 & 7.27 & 7.14 & 7.07 & 7.01 & 6.93 & 6.73 & 6.03 & 6.00 & 5.41 & 6.93 \\
\hline $\mathrm{T}_{2}$ & 8.54 & 8.39 & 8.31 & 8.25 & 8.06 & 8.03 & 7.91 & 7.70 & 7.49 & 6.89 & 6.21 & 6.00 & 5.91 & 7.51 \\
\hline Average of periods & 8.22 & 8.07 & 7.92 & 7.79 & 7.67 & 7.59 & 7.49 & 7.36 & 7.21 & 6.81 & 6.12 & 6.00 & 5.66 & \\
\hline \multicolumn{15}{|c|}{$\mathrm{CD}(0.05) \mathrm{T}=0.02 ; \mathrm{P}=0.05 ; \mathrm{T} \times \mathrm{P}=0.07 ; \mathrm{CV} \%=0.61$} \\
\hline \multicolumn{15}{|c|}{ Color \& appearance score } \\
\hline $\mathrm{T}_{1}$ & 8.15 & 8.13 & 7.82 & 7.73 & 7.67 & 7.62 & 7.56 & 7.33 & 7.25 & 6.80 & 6.32 & 6.16 & 5.3 & 7.22 \\
\hline $\mathrm{T}_{2}$ & 8.41 & 8.33 & 8.23 & 8.16 & 8.08 & 8.01 & 7.91 & 7.77 & 7.51 & 7.17 & 6.52 & 6.21 & 5.80 & 7.55 \\
\hline Average of periods & 8.28 & 8.23 & 8.03 & 7.95 & 7.88 & 7.82 & 7.74 & 7.55 & 7.38 & 6.99 & 6.42 & 6.19 & 5.55 & \\
\hline \multicolumn{15}{|c|}{$\mathrm{CD}(0.05) \mathrm{T}=0.02 ; \mathrm{P}=0.04 ; \mathrm{T} \times \mathrm{P}=0.06 ; \mathrm{CV} \%=0.46$} \\
\hline \multicolumn{15}{|c|}{ Texture score } \\
\hline $\mathrm{T}_{1}$ & 7.90 & 7.76 & 7.50 & 7.33 & 7.25 & 7.18 & 7.04 & 7.13 & 6.91 & 6.52 & 6.31 & 6.03 & 5.61 & 6.96 \\
\hline $\mathrm{T}_{2}$ & 8.42 & 8.33 & 8.24 & 8.15 & 8.02 & 7.91 & 7.75 & 7.70 & 7.51 & 6.80 & 6.11 & 6.00 & 5.72 & 7.44 \\
\hline Average of periods & 8.16 & 8.05 & 7.87 & 7.74 & 7.64 & 7.55 & 7.39 & 7.42 & 7.21 & 6.66 & 6.21 & 6.02 & 5.67 & \\
\hline \multicolumn{15}{|c|}{$\mathrm{CD}(0.05) \mathrm{T}=0.02 ; \mathrm{P}=0.04 ; \mathrm{T} \times \mathrm{P}=0.06 ; \mathrm{CV} \%=0.48$} \\
\hline \multicolumn{15}{|c|}{ Volume expansion score } \\
\hline $\mathrm{T}_{1}$ & 7.82 & 7.75 & 7.58 & 7.34 & 7.34 & 7.16 & 7.01 & 6.92 & 6.52 & 5.98 & 5.82 & 5.73 & 5.33 & 6.79 \\
\hline $\mathrm{T}_{2}$ & 8.60 & 8.51 & 8.33 & 8.25 & 8.16 & 7.91 & 7.71 & 7.66 & 7.23 & 6.81 & 6.01 & 5.99 & 5.51 & 7.44 \\
\hline Average of periods & 8.21 & 8.13 & 7.96 & 7.80 & 7.75 & 7.54 & 7.36 & 7.29 & 6.88 & 6.40 & 5.92 & 5.86 & 5.42 & \\
\hline \multicolumn{15}{|c|}{$\mathrm{CD}(0.05) \mathrm{T}=0.01 ; \mathrm{P}=0.03 ; \mathrm{T} \times \mathrm{P}=0.04 ; \mathrm{CV} \%=0.30$} \\
\hline
\end{tabular}




\begin{tabular}{|c|c|c|c|c|c|c|c|c|c|c|c|c|c|c|}
\hline \multicolumn{10}{|c|}{ Overall acceptability score } \\
\hline $\mathrm{T}_{1}$ & 7.62 & 7.50 & 7.33 & 7.21 & 7.17 & 6.98 & 6.90 & 6.83 & 6.77 & 6.24 & 5.90 & 5.90 & 5.22 & 6.74 \\
\hline $\mathrm{T}_{2}$ & 8.53 & 8.27 & 8.27 & 8.14 & 7.98 & 7.92 & 7.75 & 7.51 & 7.36 & 6.92 & 6.40 & 6.21 & 5.62 & 7.45 \\
\hline Average of periods & 8.08 & 7.89 & 7.80 & 7.68 & 7.58 & 7.45 & 7.33 & 7.17 & 7.07 & 6.58 & 6.15 & 6.06 & 5.42 & \\
\hline \multicolumn{10}{|c|}{$\mathrm{CD}(0.05) \mathrm{T}=0.02 ; \mathrm{P}=0.06 ; \mathrm{T} \times \mathrm{P}=0.08 ; \mathrm{CV} \%=0.69$} \\
\hline
\end{tabular}

The changes in the flavour, colour and appearance, texture, volume expansion and overall acceptability scores of the treatments (T1 and T2) and interaction effect between the treatments and periods were significant $(P<0.05)$. This shows that there was significant $(P<0.05)$ effect of change in formulation on storage stability of product with respect to flavour, colour and appearance, texture, volume expansion and overall acceptability characteristics.

The flavour scores of control extruded food $\mathrm{T} 1$ decreased below 7.0 (which stands for like moderately on 9-point hedonic scale) after 120 days of storage while that of WPC based extruded food T2 decreased below 7.0 after 135 days of storage at $37 \pm 2{ }^{\circ} \mathrm{C}$. But the flavour score of both the T1 and T2 were less than 6.0 (which stands for like slightly on 9point hedonic scale) on $180^{\text {th }}$ day of storage.

The colour and appearance score and texture score of both T2 and T1 decreased below 6.0 (which stands for like slightly on 9 -point hedonic scale) after 180 days of storage at $37 \pm 2{ }^{\circ} \mathrm{C}$.

The changes in the scores of volume expansion shows that there was significant $(P<0.05)$ effect of change in formulation (incorporation of WPC-70) on storage stability of product. The volume expansion scores of control extruded food T1 decreased below 6.0 (which stands for like slightly on 9-point hedonic scale) after 135 days of storage while that of WPC based extruded snack food T2 decreased below 6.0 after 165 days of storage at $37 \pm 2{ }^{\circ} \mathrm{C}$.

The overall acceptability scores of control extruded food T1 decreased below 6.0 (which stands for like slightly on 9-point hedonic scale) after 150 days of storage while that of WPC based extruded snack food T2 decreased below 6.0 after 180 days of storage at $37 \pm 2{ }^{\circ} \mathrm{C}$. The overall acceptability score of milk solids based extruded snack food T2 was below 6.0 on 180th day of storage at $37 \pm 2{ }^{\circ} \mathrm{C}$, so the storage study was discontinued after 180 days. Based on sensory evaluation it was concluded that whey protein concentrate based extruded snack food T2 packaged in MET PET was acceptable up to 165 days of storage at $37 \pm 2{ }^{\circ} \mathrm{C}$.

Raja et al. (2014) ${ }^{[14]}$ observed that the initial average score for flavour, appearance, texture, crispiness and overall acceptability characteristics the extruded fish curls sample decreased after 28 days at ambient storage.

Ali et al. (2016) ${ }^{[1]}$ observed that the initial average score for taste, color, crispiness, chewiness, pore distributions, surface characteristics and overall acceptability of the extruded products prepared from corn grits - corn starch with common carp fish decreased after 3 months at ambient storage.
Singh et al. (2017) ${ }^{[17]}$ reported that the initial score for flavour, appearance, texture and overall acceptability characteristics of corn and chickpea based extruded food decreased after 3 months during storage at ambient temperature.

\section{Changes in the Physico-Chemical Characteristics of Whey Protein Concentrate Based Extruded Snack Food during Storage}

The moisture content of $\mathrm{T} 1$ and $\mathrm{T} 2$ increased from 3.50 and 3.64 percent on zero day to 5.30 and 4.94 percent respectively at the end of 180 days of storage at room temperature $(37 \pm 2$ $\left.{ }^{\circ} \mathrm{C}\right)$ as shown in Table 2. The interaction effect between the treatments and periods were significant $(P<0.05)$ for changes in moisture content. The increase in moisture content was due to hygroscopic nature of extrudates (Butt et al., 2004). The water activity of $\mathrm{T} 1$ and $\mathrm{T} 2$ increased from 0.324 and 0.322 on zero day to 0.47 and 0.46 respectively at the end of 180 days of storage at room temperature $\left(37 \pm 2{ }^{\circ} \mathrm{C}\right)$. The changes in the water activity among the treatments $\mathrm{T} 1$ and $\mathrm{T} 2$ and the interaction effect between the treatments (T1 and $\mathrm{T} 2)$ and periods were significant $(P<0.05)$. This shows that there is significant $(P<0.05)$ effect of change in formulation on storage stability of product with respect to water activity. The slight increase of water activity in extrudates was possibly due to the change in humidity of the surrounding environment (Nissar et al., 2017) ${ }^{[11]}$.

Charunuch et al. (2008) reported increase in moisture content in Thai rice extruded snack supplemented with mulberry from 3.5 to 5 percent during storage of 4 months.

Pawar et al. (2012) ${ }^{[13]}$ observed that water activity and moisture content of egg-based snack food increased gradually from the initial value of 0.25 to 0.34 and 2.07 to 2.75 respectively, when stored for 6 months at ambient temperature. Increase in water activity during storage could be due to increase in moisture content.

Sharma et al. (2015) observed that the initial average moisture and water activity of the millet-cowpea extruded snacks samples increased from 5.9 percent and 0.49 to 8.8 percent and 0.60 respectively after 4 months of storage at ambient storage.

Nissar et al. (2017) ${ }^{[11]}$ observed that the initial average moisture and water activity of the corn-based breakfast snacks samples increased from 3.36 percent and 0.42 to 4.68 percent and 0.53 after 90 days at ambient storage.

Table 2: Influence of storage period on physico-chemical characteristics of extruded snack foods

\begin{tabular}{|c|c|c|c|c|c|c|c|c|c|c|c|c|c|c|}
\hline \multirow{2}{*}{ Types of extruded food } & \multicolumn{13}{|c|}{ Storage period (day) } & \multirow{2}{*}{ Average of treatments } \\
\hline & $\mathbf{0}$ & 15 & 30 & 45 & 60 & 75 & 90 & 105 & 120 & 135 & 150 & 165 & 180 & \\
\hline \multicolumn{14}{|c|}{ Moisture (\%) } & \\
\hline $\mathrm{T}_{1}$ & 3.50 & 3.92 & 4.17 & 4.27 & 4.37 & 4.45 & \begin{tabular}{|l|}
4.53 \\
\end{tabular} & 4.55 & 4.64 & \begin{tabular}{|l|}
4.72 \\
\end{tabular} & \begin{tabular}{|l|l|}
4.92 \\
\end{tabular} & \begin{tabular}{|l|}
5.19 \\
\end{tabular} & 5.30 & 4.55 \\
\hline $\mathrm{T}_{2}$ & 3.64 & 3.86 & 4.06 & 4.16 & 4.28 & 4.36 & 4.47 & 4.51 & 4.57 & 4.65 & 4.76 & 4.85 & 4.94 & 4.39 \\
\hline Average of periods & 3.68 & 3.89 & 4.11 & 4.22 & 4.33 & 4.41 & 4.50 & 4.53 & 4.61 & \begin{tabular}{|l|}
4.69 \\
\end{tabular} & 4.84 & 5.02 & 5.12 & \\
\hline \multicolumn{15}{|c|}{$\mathrm{CD}(0.05) \mathrm{T}=0.01 ; \mathrm{P}=0.02 ; \mathrm{T} \times \mathrm{P}=0.03 ; \mathrm{CV} \%=0.46$} \\
\hline \multicolumn{15}{|c|}{ Water Activity $\left(\mathbf{a}_{\mathrm{w}}\right)$} \\
\hline $\mathrm{T}_{1}$ & 0.324 & 0.327 & 0.347 & 0.363 & 0.377 & 0.391 & 0.403 & 0.417 & 0.425 & 0.433 & 0.446 & 0.449 & 0.463 & 0.397 \\
\hline $\mathrm{T}_{2}$ & 0.322 & 0.325 & 0.337 & 0.345 & 0.363 & 0.385 & 0.397 & 0.401 & 0.417 & 0.424 & 0.437 & 0.447 & 0.453 & 0.394 \\
\hline Average of periods & 0.323 & 0.326 & 0.342 & 0.354 & 0.370 & 0.388 & 0.400 & 0.409 & 0.421 & 0.428 & 0.442 & 0.448 & 0.585 & \\
\hline
\end{tabular}




\begin{tabular}{|c|}
\hline $\mathrm{CD}(0.05) \mathrm{T}=0.030 ; \mathrm{P}=0.002 ; \mathrm{T} \times \mathrm{P}=0.005 ; \mathrm{CV} \%=0.73$ \\
\hline $\mathrm{T}_{1}=$ Control extruded food \\
$\mathrm{T}_{2}=\begin{array}{c}\text { Whey protein concentrate based extruded food } \\
\text { Values are mean of three replications. }\end{array}$ \\
\hline
\end{tabular}

Changes in the Textural Characteristics of Whey Protein Concentrate Based Extruded Snack Food during Storage The changes in textural characteristics of WPC based extruded snack food and control during storage is shown in Table 3. The hardness of $\mathrm{T} 1$ and $\mathrm{T} 2$ increased from 1305.21 and $1425.43 \mathrm{~g}$ force on zero day to 1619.45 and $1650.84 \mathrm{~g}$ force respectively at the end of 180 days of storage at room temperature $\left(37 \pm 2{ }^{\circ} \mathrm{C}\right)$. The fracturability of control sample $\mathrm{T} 1$ and milk solids extruded snack foodT2 decreased from $4.95 \mathrm{~mm}$ and $5.42 \mathrm{~mm}$ to $3.54 \mathrm{~mm}$ and $4.52 \mathrm{~mm}$ respectively at the end of 180 days of storage at room temperature ( $37 \pm 2$ $\left.{ }^{\circ} \mathrm{C}\right)$.

The changes in the hardness among the treatments $\mathrm{T} 1$ and $\mathrm{T} 2$ were significant $(P<0.05)$ but the interaction effect between the treatments (T1 and $\mathrm{T} 2)$ and periods were non-significant $(P>0.05)$. The changes in the scores of fracturability among the treatments (T1 and T2) and the interaction effect between the treatments and periods were significant $(P<0.05)$ for fracturability.

Increase in hardness during storage may be due to increase in the moisture content of extrudates as shown in Table 2 resulting in an increase in the starch bonding. The change in hardness of the product may be observed due to the starch gelatinization and texture of the final product. Previous studies also reported that the hardness of the product increased due to increase in the moisture content of the product (Badrie \& Mellowes, 1991).

Marques et al. (2017) ${ }^{[10]}$ demonstrated that the initial hardness of extruded snack coated with corn samples as 6.59 $\mathrm{N}$, which increased up to $16.04 \mathrm{~N}$ during 45 days of storage.

Changes in the Microbial Quality of Whey Protein Concentrate Based Extruded Snack Food during Storage

The Standard plate count $(\log 10 \mathrm{cfu} / \mathrm{g})$ of $\mathrm{T} 1$ and $\mathrm{T} 2$ decreased from 4.30 and 4.26 on zero day to 2.98 and 2.87 respectively at the end of 180 days of storage at room temperature $\left(37 \pm 2{ }^{\circ} \mathrm{C}\right)$ shown in Table 4 . The changes in the SPC count among the treatments $\mathrm{T} 1$ and $\mathrm{T} 2$ and the interaction effect between the treatments (T1 and $\mathrm{T} 2)$ and periods were non-significant $(P>0.05)$. This was expected because none of the microorganisms, including bacteria as well as molds and yeasts, are able to grow in water activity less than 0.60 (Anderson, 2004) and water activity of both experimental samples were below 0.6 throughout the storage. Pawar et al. (2012) ${ }^{[13]}$ observed that standard plate count of egg-based snack food decreased gradually from the initial value of 4.4 to $3.3 \log \mathrm{cfu} / \mathrm{g}$ when stored for 6 months at ambient temperature.

Throughout the storage study yeast and mold count and coliform count were not detected in both experimental samples $\mathrm{T} 1$ and $\mathrm{T} 2$.

Table 3: Influence of storage period on textural characteristics of extruded snack foods

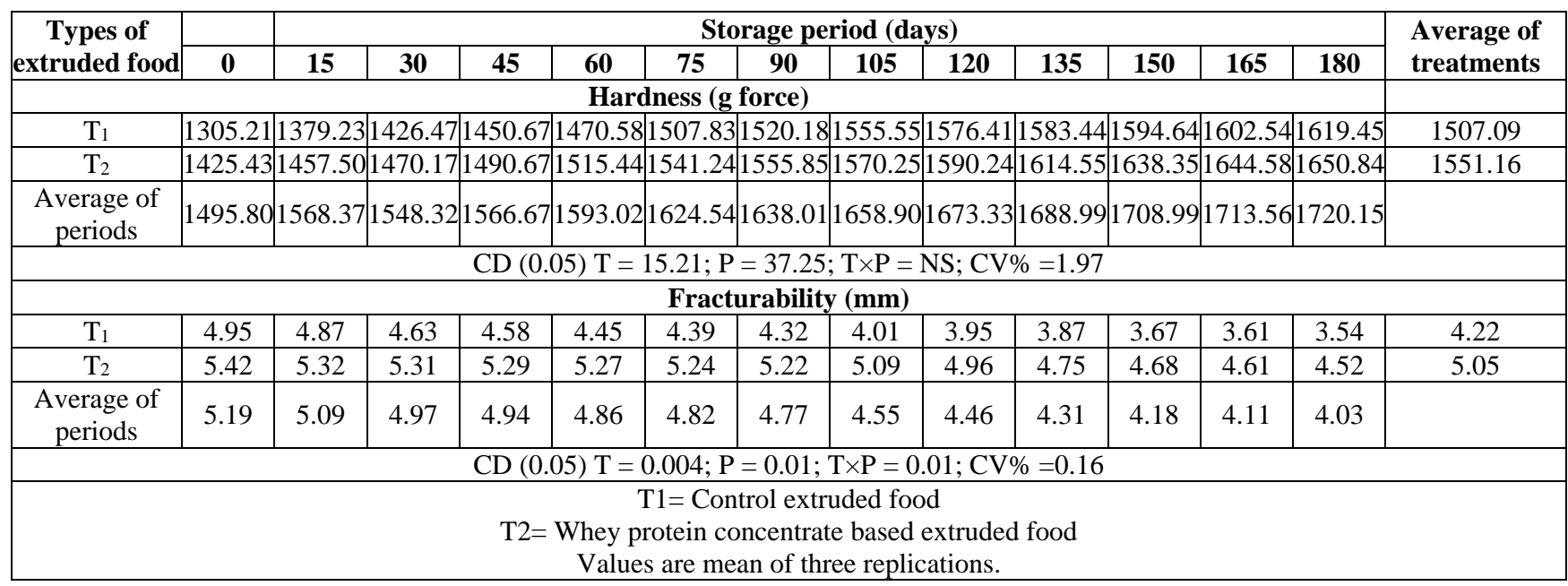

Table 4: Influence of storage period on SPC count of extruded snack foods

\begin{tabular}{|c|c|c|c|c|c|c|c|c|c|c|c|c|c|c|}
\hline \multirow{3}{*}{$\begin{array}{c}\text { Types of } \\
\text { extruded food }\end{array}$} & \multicolumn{13}{|c|}{ Storage period (day) } & \multirow{3}{*}{ Average of treatments } \\
\hline & \multicolumn{13}{|c|}{ Standard Plate Count $(\log c f u / g)$} & \\
\hline & $\mathbf{0}$ & 15 & 30 & 45 & 60 & 75 & 90 & 105 & 120 & 135 & 150 & 165 & 180 & \\
\hline $\mathrm{T}_{1}$ & 4.30 & 4.27 & 4.27 & 4.21 & 4.02 & 4.06 & 3.99 & 3.88 & 3.73 & 2.30 & 2.99 & 2.99 & 2.98 & 3.69 \\
\hline $\mathrm{T}_{2}$ & 4.26 & 4.22 & 4.17 & 4.06 & 4.07 & 3.98 & 3.90 & 3.79 & 3.58 & 3.19 & 2.99 & 2.91 & 2.87 & 3.69 \\
\hline Average of periods & 4.28 & 4.25 & 4.22 & 4.14 & 4.04 & 4.02 & 3.95 & 3.84 & 3.66 & 2.75 & 2.99 & 2.95 & 2.93 & \\
\hline \multicolumn{15}{|c|}{$\mathrm{CD}(0.05) \mathrm{T}=\mathrm{NS} ; \mathrm{P}=0.412 ; \mathrm{TP}=\mathrm{NS} ; \% \mathrm{CV}=9.38$} \\
\hline \multicolumn{15}{|c|}{$\begin{array}{c}\mathrm{T}_{1}=\text { Control extruded food } \\
\mathrm{T}_{2}=\text { Whey protein concentrate based extruded food } \\
\text { Values are mean of three replications. }\end{array}$} \\
\hline
\end{tabular}

\section{Conclusion}

The whey protein concentrate based extruded snack food and control sample were stored at room temperature $\left(37 \pm 2{ }^{\circ} \mathrm{C}\right)$ after packaging in MET PET material. All the sensory parameters viz. flavour, colour and appearance, texture, volume expansion and overall acceptability scores decreased 
significantly over a period of 180 days of storage. The moisture content decreased while water activity of experimental sample and control increased at the end of 180 days of storage at room temperature $\left(37^{\circ} \pm 2{ }^{\circ} \mathrm{C}\right)$. Textural characterisitics viz. hardness increased while the changes in the fracturability among the treatments and the interaction effect between the treatments and periods were significant. The Standard plate count of both, experimental sample and control, decreased at the end of 180 days of storage at room temperature $\left(37^{\circ} \pm 2{ }^{\circ} \mathrm{C}\right)$. Coliform and yeast and mold count were not detected in both experimental samples throughout the study period. The overall acceptability score of WPCs based extruded snack food was below 6.0 on $180^{\text {th }}$ day of storage hence it was concluded that APC based extruded snack food packaged in MET PET was acceptable up to 165 days of storage at $37 \pm 2{ }^{\circ} \mathrm{C}$.

\section{References}

1. Ali H, Mansour E, Osheba1 A, ElBedawey A. Evaluation of extruded products prepared from corn grits - corn starch with common carp fish. American Journal of Food Science and Nutrition Research. 2016; 3(5):102-108.

2. Anton AA, Fulcher RG, Arntfield SD. Physical and nutritional impact of fortification of corn starch-based extruded snacks with common bean (Phaseolus vulgaris L.) flour: effects of bean addition and extrusion cooking. Food Chemistry. 2009; 113(4):989-996.

3. Brennan MA, Derbyshire E, Tiwari BK, Brennan CS. Ready-to-eat snack products: the role of extrusion technology in developing consumer acceptable and nutritious snacks. International Journal of Food Science and Technology. 2013; 48(5):893-902.

4. Bureau of Indian Standards Handbook, (BIS: Part XI,). Handbook of Food analysis, Dairy Products. Indian Standards Institution, Manak Bhavan, New Delhi, 1981.

5. Cai W, Diosady LL, Rubin LJ. Degradation of wheat starch in a twin-screw extruder. Journal of Food Engineering. 1995; 26(3):289-300.

6. Chaiyakul S, Jangchud K, Jangchud A, Wuttijumnong P, Winger R. Effect of extrusion conditions on physical and chemical properties of high protein glutinous rice-based snack. LWT - Food Science and Technology. 2009; 42(3): 781-787.

7. Charunuch C, Tangkanakul P, Rungchang S, Sonted V. Application of mulberry (Morus alba L.) for supplementing antioxidant activity in extruded Thai rice snack. Kasetsart Journal (Natural Sciences). 2008; 42:19.

8. Conti-Silva AC, Bastos DHM, Areas JAG. The effects of extrusion conditions and the addition of volatile compounds and flavor enhancers to corn grits on the retention of the volatile compounds and texture of the extrudates. International Journal of Food Science and Technology. 2012; 47(9):1896-1902.

9. Huber G. Snack foods from cooking extruders. In Lusas, E. W. \& Rooney, L. W. (Eds.), Snack Food Processing (pp.315-367). Baca Raton, FL, CRC Press, 2001.

10. Marques D, Berwig P, Monteiro CF, Oliveira M, Monteiro A. Shelf life evaluation of extruded snacks coated with maize starch to eliminate the use of fats in the flavouring process. Chemical Engineering. 2017; 57:1921-1926.

11. Nissar J, Ahad T, Naik HR, Hussain S, Rather AH. Studies on storage stability of corn-based apple incorporated breakfast snacks. International Journal of Chemical Studies. 2017; 5(6):839-841.

12. Pastor-Cavada E, Drago SR, González RJ, Juan R, Pastor JE, Alaiz M. et al Effects of the addition of wild legumes (Lathyrus annuus and Lathyrus clymenum) on the physical and nutritional properties of extruded products based on whole corn and brown rice. Food Chemistry. 2011); 128 (4):961-967.

13. Pawar D, Raj K, Modi VK. Physico-chemical, microbiological and sensory characteristics of egg basede snack food. Journal of Scientific \& Industrial Research. 2012; 71(12):777-787.

14. Raja W, Kumar S, Bhat Z, Kumar P. Effect of ambient storage on the quality characteristics of aerobically packaged fish curls incorporated with different flours. Springer Plus. 2014; 3(1):106.

15. Sebastian RS, Cleveland LE, Goldman JD. Effect of snacking frequency on adolescents' dietary intakes and meeting national recommendations. Journal of Adolescent Health. 2008; 42(5):503-511.

16. Sharma S, Mansour M, Bobade H, Kaur G, Singh B. Product characteristics and storage stability of milletcowpea extruded snacks. Agricultural Research Journal. 2015; 52(4):68-72.

17. Singh G, Singh B, Sharma S, Singh A. Development and storage study of maize and chickpea based extruded snacks. International Journal of Current Microbiology and Applied Sciences. 2017; 6(10):4798-4804.

18. Zheng $X$, Wang SS. Shear induced starch conversion during extrusion. Journal of Food Science. 1994; 59(5):1137-1143. 